SEM-EDS analysis of ancient gold leaf glass mosaic tesserae. A contribution to the dating of the materials

This content has been downloaded from IOPscience. Please scroll down to see the full text. 2012 IOP Conf. Ser.: Mater. Sci. Eng. 32012007

(http://iopscience.iop.org/1757-899X/32/1/012007)

View the table of contents for this issue, or go to the journal homepage for more

Download details:

IP Address: 23.22.50.124

This content was downloaded on 28/05/2016 at 19:42

Please note that terms and conditions apply. 


\title{
SEM-EDS analysis of ancient gold leaf glass mosaic tesserae. A contribution to the dating of the materials
}

\author{
A Conventi ${ }^{1,3}$, E Neri $^{2}$ and $M$ Verità ${ }^{1}$ \\ ${ }^{1}$ Università IUAV di Venezia, Laboratorio Analisi Materiali Antichi, Palazzo Badoer, \\ San Polo 2468/B, IT-30125 Venice-Murano, Italy \\ ${ }^{2}$ Università Cattolica del Sacro Cuore, Milan, Italy \\ E-mail: alberto.conventi@iuav.it
}

\begin{abstract}
Metal leaf (gold, silver or their alloys) glass tesserae began to be used in wall mosaics in the first century AD (the first examples are in Rome) and their use has been uninterrupted up to day.

The metal leaf could be obtained from circulating coins, jewellery or refining. According to various techniques that have changed over the centuries, the leaf was hot fixed between two glass layers.

From an archaeological point of view, it is interesting to know when and where these tesserae were made, if they were new made or if they were reused tesserae recovered from earlier dismantled mosaics.

The determination of the glass composition of the tesserae is not of great help in this connection, for the same kind of glass was used over long periods. Available information is still scanter for glasses produced between the 1st to 8th centuries when the batch of raw materials (a natural soda called natron and a silica-lime sand) was melted in large tank furnaces and chunks of raw glass were transported all over the Mediterranean to be remelted and shaped into manufacts in small pot furnaces.

The SEM-EDS analysis is proposed in this study as a useful tool to investigate the composition of both the glass and the gold alloy in leaf tesserae from mosaics of the 1st - 9th centuries. The comparison of the composition of the gold leaf of the tesserae with that of circulating gold coins (for which an important analytical data base is available), adds further information to the glass analysis, allowing us to improve the dating of the tesserae and increase the knowledge that may result from scientific analyses. The results demonstrate that good quantitative analyses of the metal leaf can be performed and that metal leaves made of pure gold or goldsilver alloys were used.
\end{abstract}

\section{Introduction}

A mosaic consists of cube-shaped small pieces of different materials and colours, known as tesserae, which are held in place by mortar and generally separated by visible interstices. Glass is an ideal material for tesserae because it provides a rich polychrome decoration, is easy to cut from poured glass cakes and is a durable material. The earliest examples of wall and vault decoration with glass tesserae date to the 1st century AD. The technique of colouring glass tesserae with a metal leaf dates back to the same period; the first examples are in Rome [1].

\footnotetext{
3 To whom any correspondence should be addressed.
} 
The metal leaf tesserae are real composite materials made of a leaf of gold or silver hot fixed between two glass layers (figure 2). The glass embedded in the mortar (the support) is 5 to $10 \mathrm{~mm}$ thick, while a thin sheet of blown glass (the cartellina, usually 0.3 to $0.7 \mathrm{~mm}$ thick) protects the fragile metal foil and adds to its brilliance [2]. These tesserae are made also today by laying the beaten square metal leaf (less than $1 \mu \mathrm{m}$ thick) on a small piece of blown glass (less than $1 \mathrm{~mm}$ thick). Molten glass is then poured on the leaf; the whole piece is heated in the furnace and then pressed to form a cake and to ensure good adhesion of the three layers. The tesserae are then cut from these cakes.

From an archaeological point of view, it is interesting to know when and where these tesserae were made and the technology adopted to prepare them. In this paper, scanning electron microscopy equipped with energy-dispersive X-ray spectrometry (SEM-EDS) analysis is applied to determine the quantitative composition of gold leaves of tesserae from mosaics of the 1st to 9th centuries. The aim was to verify whether the metal composition corresponds to the composition of contemporary circulating gold coins, jewels or was prepared from refined gold. In the first case, due to the fact that the composition of the gold coins changed during the considered period, the analyses of the metal will add to the scant information obtained by the glass analysis, allowing us to improve the dating of the tesserae and to identify their provenance.

\section{Experimental}

\subsection{Gold leaf tesserae}

More than thirty gold leaf tesserae from mosaics in Italy (Rome, Ravenna and Milan) dated to between the 1 st and 9th centuries A.D. were analyzed. The tesserae were sampled during restoration of in situ mosaics or during archaeological excavation. In Table 1 the provenance of the analyzed tesserae is reported.

Table 1. Provenance of the analyzed tesserae. (*): archaeological sites.

\begin{tabular}{lccc}
\hline mosaic & century & n. of samples & reference \\
\hline Rome* & 1st & 2 & {$[1]$} \\
Aquileia* & 1st-4th & 2 & {$[15]$} \\
Ostia, Rome* & 4 th & 4 & {$[16]$} \\
Rome, St Pudenziana & 4 th & 1 & {$[17]$} \\
Rome, St Sabina & 5 th & 4 & \\
Ravenna, St Apollinare Nuovo & 5 th & 4 & \\
Milan, St Lorenzo & 5 th & 2 & \\
Milan, St Giovanni alle Fonti & 5 th-6th & 6 & \\
Ravenna, St Vitale & 6th & 6 & \\
Rome, Sts Cosma e Damiano & 7 th & 2 & {$[18]$} \\
Rome, St Stefano Rotondo & 7 th & 4 & {$[19]$} \\
Rome, St Cecilia & 9 th & 3 & {$[20]$} \\
\hline
\end{tabular}

When intact tesserae were available, fragments including the support, gold leaf and cartellina were cut with a rotating diamond wheel and embedded in cross-section in acrylic resin in a teflon mould. 
The discs were ground and polished down to $3 \mu \mathrm{m}$ grain size diamond pastes. When only the support or the cartellina was available (weathered tesserae), samples were stacked to a stub, so that the surface originally in contact with the gold leaf was exposed to the electron beam. In secondary or backscattered electron mode, also small residues of the gold leaf can be easily detected (figure 1).

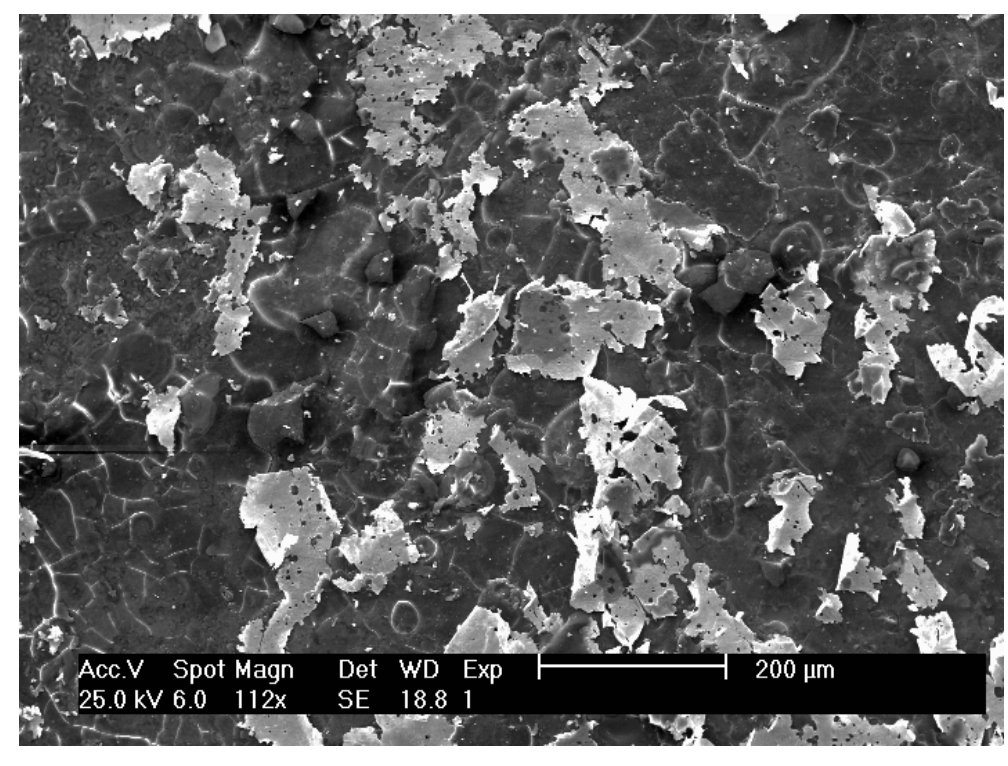

Figure 1. Small residues of the gold leaf on a cartellina (the large bright part of the image).

\subsection{Methods}

After observation with an optical microscope in reflected light, samples were carbon coated to be analyzed by scanning electron microscopy (Philips XL 30). The quantitative X-ray microanalysis of the glass of the cartellina and of the support was done by wavelength-dispersive X-ray microanalysis using a Cameca SX-50. Various reference glasses of certified composition were analyzed under the same experimental conditions to verify the accuracy of the method.

The microprobe was equipped with three wavelength-dispersive X-ray spectrometers (PET, LiF and TAP crystals). Twenty elements were quantified: $\mathrm{X}$-ray $\mathrm{K} \alpha$-lines were analyzed except for $\mathrm{Pb}$ and $\mathrm{Bi}(\mathrm{M} \alpha$-lines), Sb, As and $\mathrm{Sn}$ (L $\alpha$-lines). Operating conditions were: accelerating potential $15 \mathrm{kV}$, beam current $20 \mathrm{nA}$ (major and minor components) or $100 \mathrm{nA}$ (trace elements) respectively. A 40x50 $\mu \mathrm{m}$ scanning electron beam and limited counting time (10 $\mathrm{s}$ for major and minor elements, 20 to $30 \mathrm{~s}$ for traces) were employed to ensure that no significant alkali drift (ion migration) occurred during the irradiation. The net X-ray intensities (peak minus background) were quantified by means of a PAP correction programme supplied by Cameca. X-ray microanalysis applied to the glass analysis is discussed in [3].

Quantitative analysis of the metal leaf was performed by energy-dispersive X-ray microanalysis (Edax). In a SEM image at 4000 magnifications of the tesserae cross-sections, the electron beam was scanned across an area $5 \mu \mathrm{m}$ long and as wide as the gold leaf (less than $1 \mu \mathrm{m}$ ). The aim was to investigate during the analysis a metal volume as much representative as possible of the gold foil as a whole. The analysis was repeated in three areas for each sample and the average value was considered. Special care was taken to carry out the analysis on areas free of cavities (bubbles) and deposits formed at the glass-gold boundary during the hot forming of the glass cake. A standardless ZAF correction of the raw data was performed. To verify the accuracy of the method, Au-Ag and $\mathrm{Au}-\mathrm{Cu}$ reference alloys were analyzed under the same experimental conditions as for metal leaves. The calculated concentration values agreed within $5 \%$ with the concentrations of the certified samples. 
During analysis SEM operates at $20 \mathrm{kV}$, with beam intensity adjusted to give an input rate of approximately 1500 count per second (cps) and counting live-time of $200 \mathrm{~s}$. These analytical conditions allowed us to calculate a lower limit of detection (determined as three standard deviation of the background on a ternary reference alloy: $\mathrm{Au} 96 \%$; $\mathrm{Ag} 2.5 \%$; $\mathrm{Cu} 2.5 \%$ ) of $0.10 \mathrm{wt} \%$ for silver $(\mathrm{Ag}, \mathrm{L} \alpha)$ and $0.20 \mathrm{wt} \%$ for copper $(\mathrm{Cu}, \mathrm{K} \alpha)$. The lead $(\mathrm{Pb}$ less than $300 \mathrm{ppm})$ and platinum (Pt less than $500 \mathrm{ppm}$ ) contents found in Roman gold coins [4] are under the lower limit of detection of the analytical method and were not investigated.

\section{Results and discussion}

\subsection{Glass analysis}

The analyses demonstrate that the composition of the cartellina (thickness varies between 0.5 and $0.7 \mathrm{~mm}$ ) is practically the same as that of the support for most of the tesserae. The optical quality, however, is different: the cartellina glass is homogeneous while the support glass is heterogeneous and contains many bubbles (figure 2).

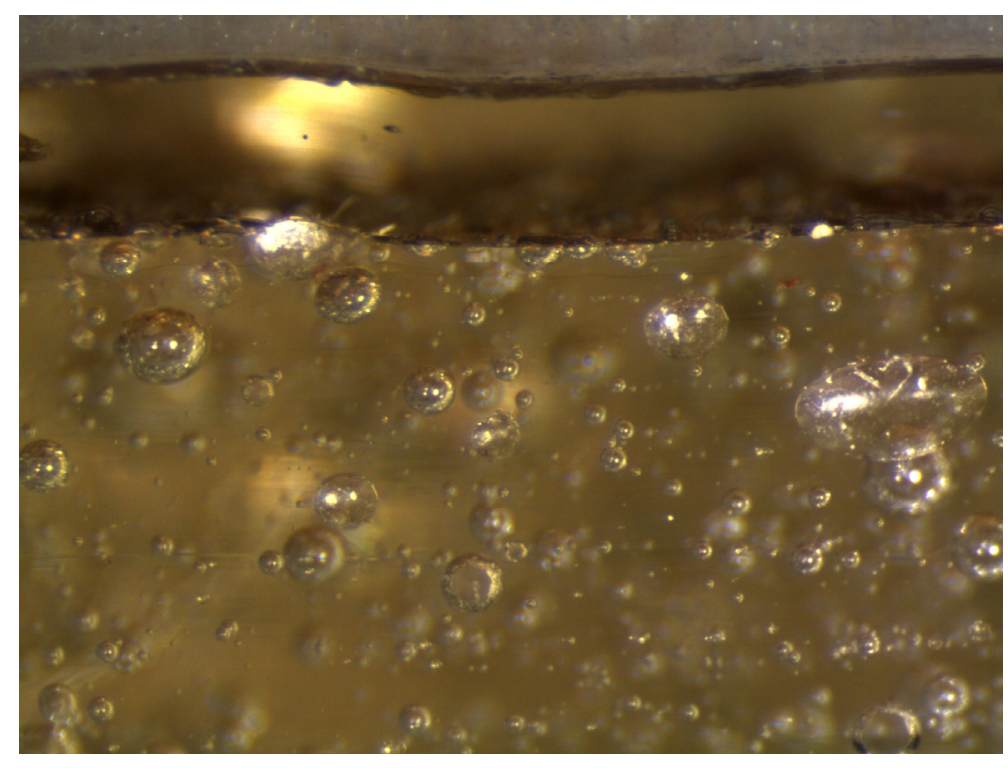

Figure 2. Optical micrograph of the polished section of the cartellina and support glass (gold leaf tessera from the mosaic of St Stefano Rotondo, Rome). Short side of the micrograph: $2.5 \mathrm{~mm}$.

A thickness in the range 0.3 to $0.7 \mathrm{~mm}$ was measured for most of the cartellina. Only rarely was the cartellina deliberately coloured slightly purple or well decolorized on a light green support.

The cartellina glass composition differs from that of the support only in few tesserae. For instance, in a tessera from Aquileia (AQ659g) the two layers have the same glass composition (iron included: $\mathrm{Fe}_{2} \mathrm{O}_{3} 0.50 \%$ ) except for decolourants. The cartellina is better decolourized with manganese and antimony ( $\mathrm{MnO} 0.28 \% ; \mathrm{Sb}_{2} \mathrm{O}_{3} 0.32 \%$ ), as compared to the support, which is decolourized only with manganese ( $\mathrm{MnO} 1.10 \%)$.

As expected for this period, the main glass components are the oxides of sodium, calcium and silicon (soda-lime-silica glass), while the oxides of potassium and magnesium are each below about $1.5 \%$ and phosphorous below $0.2 \%$. This composition is in agreement with the dominant glass type from the Roman time until the 8th - 9th centuries AD (later, glass was made by melting silica and plant ash), which was made by melting a batch of a sodium carbonate mineral from Egypt, called natron, mixed together with a natural silica-lime sand in which quartz and calcium carbonate were present in suitable ratios to make glass [5]. In this period the melting of the batch of raw materials was carried out in a limited number of places located near the sources of the raw materials (the Levant, 
Egypt), in tank furnaces where several tons of glass could be melted. Once the melting was completed, the furnace was left to cool and then demolished. Blocks of transparent glass were recovered (raw glass), traded throughout the Mediterranean region and Western Europe and distributed to workshops where they were remelted and made into objects. The analytical investigations confirm this model; in fact only a few glass groups can be distinguished by their composition in the period between the 1st and 9th centuries AD [5]. The division of the production process among a few primary melting centres and many secondary fabrication workshops restricts the contribution that chemical analyses can give to the understanding of the place of production and the circulation of the finished glass tesserae.

The final appearance and shade of metal-leaf tesserae depend on various parameters such as the metal used (gold or silver), the colour of the support and of the cartellina. Because the metal leaves are so thin, they often fail to provide a uniform layer and discontinuities occur, through which the glass support may be seen. Thus the colour of the support can influence the chromatic effect of the tesserae. Though it has been poorly studied, the use of different types of gold tesserae in the same mosaic seems to have been a widespread practice in Late Antiquity and Byzantine ages. Preliminary investigations in Milan [6] and Ravenna [7] contexts confirm the use of two kinds of gold leaf tesserae in the same mosaic: one made with a colourless glass and the second with a yellow-green glass. This confirms a deliberate choice according to an aesthetic principle intended to give the gold leaf a different luminosity: a silvery effect on a colourless support and a warmer one on a yellow-green glass. The analyses of the Milan gold leaf tesserae reveal that yellow green glass was obtained by using sand with high amounts of contaminants (high iron, titanium and alumina concentrations) and only partially decolourizing the glass with manganese. These compositional characteristics are compatible with a natron glass type termed HIMT (high iron, manganese and titanium), which was widespread in Europe and in the Mediterranean area between the 5th and 7th centuries [5]. Instead, the perfectly colourless glass of other tesserae was obtained from purer sand (the iron content is about one half as compared to the yellow green gold tesserae) and antimony alone or in association to manganese was used for the decolouration. This type of glass was hold to be in use between the 2nd and the 4th centuries AD [8], but recent studies demonstrated that antimony was still in use at least until the 9th century [9].

\subsection{Gold leaf analysis}

A text of the 1st century AD by the physician Dioscorides Pedanius Anazarbei (De materia medica libri sex) reports that gold leaves were obtained by beating gold between two copper sheets to avoid their rupture. Pliny (Naturalis Historia, XXXIII, XI) writes that from one ounce (27.264 g) 750 leaves four inches side length $(7.4 \mathrm{~cm})$ could be obtained for marble, wood and copper gilding. The Manoscritto di Lucca (Greek tradition, late 8th century) shows that this technique was still in use in the late 8th century. This manuscript specifies for the first time (chapter 15) that the gold leaf used in mosaics is held between two layers of glass, a thin layer and a thicker one [10].

The thickness of the gold leaf was measured by SEM in SE mode in the polished cross-sections. Due to the irregular beating of the leaf in a single tessera, important differences in the thickness of the metal leaf were found. Thickness varies between $0 \mu \mathrm{m}$ (areas where the gold leaf is torn) and $0.9 \mu \mathrm{m}$; most of the measurements are in the range $0.4 \pm 0.2 \mu \mathrm{m}$. This thickness is compatible with the $0.325 \mu \mathrm{m}$ thickness calculated for medieval leaves obtained by beating a florin $(3.53 \mathrm{~g})$ to obtain (following medieval treatises) 100 leaves of about $7 \mathrm{~cm}$ width and an area of about $53 \mathrm{~cm}^{2}$ [10]. This leads to the conclusion that in the period between the 1st and 9th centuries, by beating $19.3 \mathrm{~g}$ of gold (one cubic centimetre), 2.5 to $3.0 \mathrm{~m}^{2}$ of gold leaf for mosaic tesserae were obtained.

Ancient texts do not mention the source of the gold. We have to wait for the Il libro dell'arte by Cennino Cennini (chapter 139) written in the late 14th century to learn that gold coins (ducato from Venice, in circulation in the second half of the 13th century) were beaten to make gold leaves. 13th century (second half) documents report the use of gold florine and ducate to make gold foils [11]. The hypothesis cannot be excluded that circulating gold coins were beaten to obtain gold leaves also 
during the late Roman period. Since gold coins were common currency in those days, they represented an easily accessible source of gold guaranteed by the mint. Pure gold was preferred instead of gold alloys mainly because it is malleable and ductile, therefore ideal for making the thin sheets required for the gold tesserae, but also because it is brilliant and resistant to weathering.

It is well known that high purity was generally a characteristic of circulating gold coins, while the goldsmith's art was practised be remelting gold items or gold coins. In this context, it is reasonable to assume that gold beaters preferred to obtain gold leaves directly from coins rather than remelting jewellery items and purify gold alloys. The composition of circulating gold coins varies in time and sometimes also according to the mint of coinage. For instance, in the 8th and 9th centuries the average gold content of circulating coins was about $96.4 \%$ [12].

Of the 33 gold tesserae analyzed in this work, in 9 cases the metal leaf was made of pure gold, in 8 samples gold varied in a restricted range between $99 \%$ and $99.5 \%$ and silver made up for the difference 0.5 to $1 \%$. In the remaining 16 tesserae the gold amount was less than $99 \%$, with a lowest concentration of $91 \%$, and silver completing the alloy. Small amounts of copper $(\mathrm{Cu} 0.5$ to $1 \%)$ were detected only in two tesserae from Aquileia.

These results seem to exclude the use of jewellery items as a source of the metal of the gold leaf mosaic tesserae. In jewellery, gold alloys containing copper and silver were mainly used: the gold content was between 90 and $96 \%$ in the late Roman period [13] and below $91 \%$ during the Byzantine period [4]. Instead, these results indicate marked similarities with gold coins circulating in the considered period. Analyses of gold coins circulating between the 1st and 9th centuries are published and both the period and the mint of coinage are well established for ancient gold coins.

Coins are almost invariably amenable to close dating because they are usually inscribed with the name of a known ruler. As illustrated in figure 3, which is based on the measurements performed by Callu et al. with several analytical techniques [14], in the period 63-253 AD the silver content never exceeded $1 \%$. Between 254 and 261 (Valeriano) the silver content increased to $7.8 \%$. This level decreased to $2.9 \%$ during 263-283 (Claudio) and later under $1 \%$. Since 317 until 345 the silver content is between $2-3 \%$, and between 346 until 368 it increased up to $5.1 \%$, then it decreased again to less than $1 \%$.

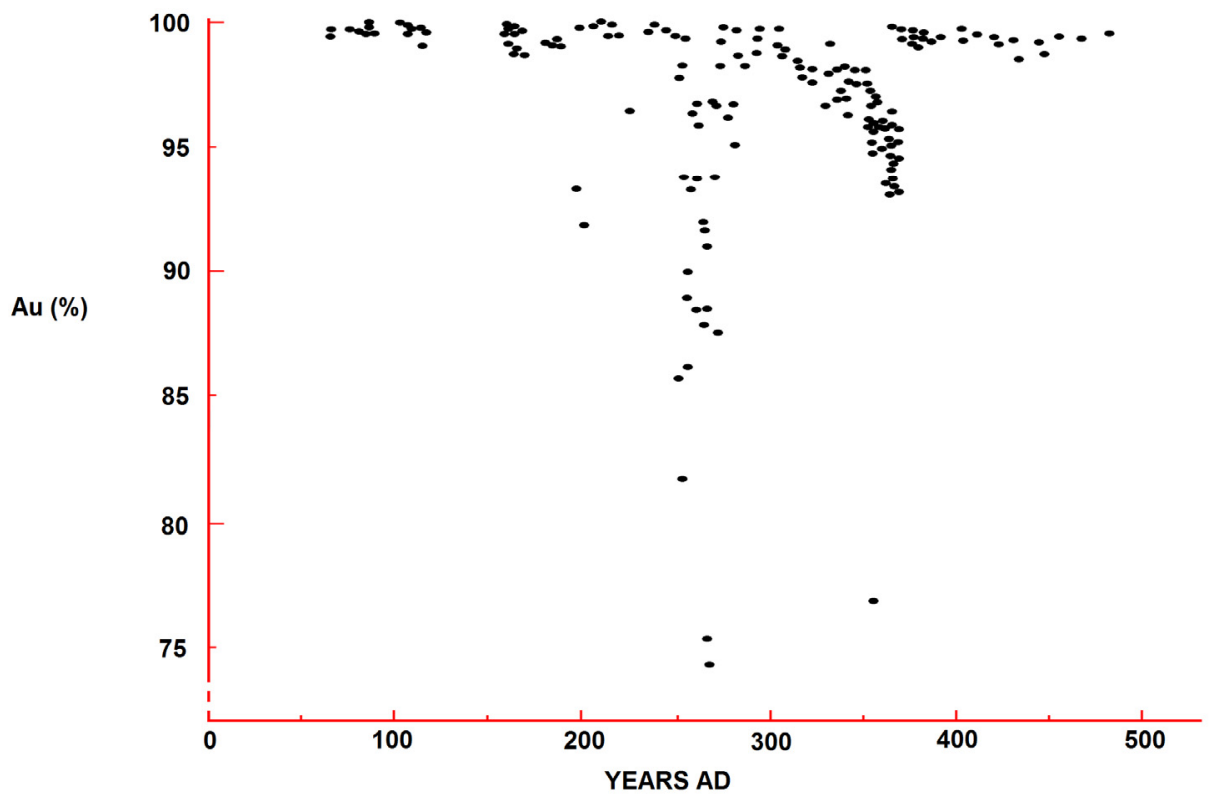

Figure 3. Composition of gold coins circulating in the early centuries from Callu et al. [14]. 
A contribution arises from the analysis of the gold leaf to distinguish reused tesserae recovered by dismantling ancient mosaics. Reuse has always been a common practice, owing to the high cost of mosaic tesserae. It is difficult to state from analytical data whether a tessera was expressly made for a given mosaic or is a reused one, because the same natron glass has been used over very long periods of time. One can observe that tesserae with a gold leaf of different composition were used for certain mosaics. As an example, the chemical analyses of four tesserae from the 5th century mosaic of St. Sabina in Rome are reported in table 2.

Table 2. Glass (wt $\%$ of oxides) and gold leaf (wt $\%$ of the elements) composition of tesserae from the 5 th century mosaic of St. Sabina, Rome.

\begin{tabular}{|c|c|c|c|c|c|c|c|c|c|c|c|c|c|c|c|}
\hline & $\mathrm{SiO}_{2}$ & $\mathrm{Al}_{2} \mathrm{O}_{3}$ & $\mathrm{Na}_{2} \mathrm{O}$ & $\mathrm{K}_{2} \mathrm{O}$ & $\mathrm{CaO}$ & $\mathrm{MgO}$ & $\mathrm{SO}_{3}$ & $\mathrm{P}_{2} \mathrm{O}_{5}$ & $\mathrm{Cl}$ & $\mathrm{TiO}_{2}$ & $\mathrm{Fe}_{2} \mathrm{O}_{3}$ & $\mathrm{MnO}$ & $\mathrm{Sb} 2 \mathrm{O} 3$ & $\mathrm{Au}$ & $\mathrm{Ag}$ \\
\hline $\begin{array}{l}\text { SSA-E(sc) } \\
\text { colourless }\end{array}$ & 68.8 & 2.05 & 19.0 & 0.44 & 5.8 & 1.00 & 0.22 & 0.12 & 1.15 & 0.08 & 0.57 & 0.53 & 0.20 & 99.6 & 0.4 \\
\hline $\begin{array}{l}\text { SSA-D(sc) } \\
\text { colourless }\end{array}$ & 68.7 & 2.11 & 19.6 & 0.64 & 5.9 & 0.54 & 0.28 & 0.16 & 1.08 & 0.05 & 0.39 & 0.13 & 0.42 & 92.5 & 7.5 \\
\hline $\begin{array}{l}\text { SSA-G(sc) } \\
\text { amber yellow }\end{array}$ & 67.4 & 1.84 & 19.9 & 0.43 & 6.7 & 0.74 & 0.29 & 0.14 & 1.15 & 0.08 & 0.53 & 0.61 & 0.20 & 99.3 & 0.7 \\
\hline $\begin{array}{l}\mathrm{SSA}-\mathrm{F}(\mathrm{sc}) \\
\text { green }\end{array}$ & 69.1 & 2.89 & 15.8 & 0.61 & 7.9 & 0.89 & 0.16 & 0.21 & 0.89 & 0.06 & 0.52 & 0.93 & & 99.6 & 0.4 \\
\hline
\end{tabular}

Important differences in glass composition are found only for the SSA-F tessera, showing a larger content of sodium ad calcium and no antimony. The gold leaf analysis clearly shows that the SSA-D tessera, similar to the SSA-E both for glass decolouration technique (manganese and antimony) and composition, has a different origin as demonstrated by the different silver content $(\mathrm{Ag} 7.5 \%$ for SSA-D, only $0.4-0.7 \%$ for SSA-E and the other tesserae).

\section{Conclusions}

An experimental method for the analysis of the gold leaves of glass mosaic tesserae by energydispersive X-ray microanalysis was set up. Lower limits of detection of $0.1 \%$ and $0.2 \%$ were calculated for silver and copper, respectively.

Analyses carried out on more than thirty mosaic tesserae of the period 1st to 9th centuries demonstrate that the leaves were made of pure gold or gold-silver alloys in a restricted range of composition, with a silver content less than $9 \%$. These data strongly suggest that circulating gold coins were beaten to make the gold foils.

In conclusion, these results seem to indicate that a comparison between the composition of the gold leaves and that of the coins circulating in different times and areas will be possible in order to obtain additional information on the dating and provenance of this kind of mosaic tesserae. In particular, comparison of compositional data can help with the identification of reused tesserae, that is, tesserae recovered from earlier mosaics or of different provenance. Further research on this subject is in progress by the authors.

\section{References}

[1] Bartoli M, Cousi V and Felici F 2008 Il mosaico parietale del ninfeo di Lucullo sotto il palazzo nuovo della biblioteca hertziana a Roma. Nuove acquisizioni e progetto di restauro. Proc. XIV Colloquio AISCOM (Spoleto, 2008) pp. 509-519

[2] Verità M 2000 Technology and deterioration of vitreous mosaic tesserae. Rev. Conservation 1 65-76

[3] Verità M, Basso R, Wypyski M T and Koestler R 1994 X-ray microanalysis of ancient glassy materials: a comparative study of wavelength dispersive and energy dispersive techniques. Archaeometry 36 241-51 
[4] Oddy W A and Niece S L 1986 Byzantine gold coins and jewellery. A study of gold content. Gold Bullettin 19 19-27

[5] Freestone I C 2005 The Provenance of ancient glass through compositional analysis. Mater. Res. Soc. Symp. Proc. 852 008.1.1-14

[6] Conventi A, Neri E and Verità M 2010 Glass mosaic tesserae from the 5th-6th century baptistery of San Giovanni alle Fonti, Milan, Italy. Analytical investigations. Proc. Conference: the New Light on Old Glass: Byzantine Glass and Mosaics. (London, 27-29 May 2010) ed. L James; in press

[7] Carbonara E, Muscolino C and Tedeschi C 1999 La luce del mosaico: le tessere d'oro di Ravenna. Tecniche di fabbricazione e utilizzo. Proc. VI Colloquio AISCOM (Venezia) pp. 709-16

[8] Jackson C 2005 Making colourless glass in the Roman Period. Archaeometry 47 763-80

[9] Verità M 2010 Indagini analitiche degli smalti dell'altare di Sant'Ambrogio a Milano: transizione verso una nuova tecnologia vetraria nel IX secolo. Proc. National A.I.Ar. Conference 2009: Riflessioni e trasparenze. Diagnosi e conservazione di manufatti vetrosi (Ravenna 2009) ed. M Vandini (Bologna: Patron) pp. 13-26

[10] Merzenich C 1996 Dorature e policromie delle parti architettoniche nelle tavole d'altare toscane fra Trecento e Quattrocento. Kermes, Dossier IX 26 51-71

[11] Travaini L 2005 Coins, gold-beaters and painters. How gold was used in wall paintings: some exemples from the Scrovegni chapel. in: Giotto in the Scrovegni Chapel: materials used in the painting technique. Studies and research by Istituto centrale per il Restauro. ed. G Basile. Bollettino d'Arte, special volume, 145-52

[12] Oddy W A 1988 The debasement of the provincial Bizantine gold coniage from the seventh to ninth centuries. in: Studies in early Byzantine gold coinage. eds. W Hahn and W Metcalf. ANS Numismatic Studies 17 135-42

[13] Yeroulanou A 1999 Diatrita:gold pierced-work jewellwry from the 3th to the 7th century. (Athens, Benaki Museum)

[14] Callu J P, Brenot C, Barrandon J N and Poirier J 1985 Aureus obryziacus. in: Or monnayé. C E Babelou. pp. 81-111

[15] Verità M 2006 Tessere vitree a foglia d'oro nei mosaici di Aquileia. Quaderni Friulani di Archeologia XVI 7-12

[16] Verità M, Arena M S, Carruba A M and Santopadre P 2009 Materiali vitrei nell'opus sectile di Porta Marina (Ostia antica). Bollettino ICR 78-94

[17] Verità M 2003 Analisi delle tessere musive. in: Il mosaico di Santa Pudenziana a Roma, il restauro, a cura di V. Tiberia. (Perugia: Ediart) pp. 178-199.

[18] Verità M, Profilo B and Vallotto M 2002 I mosaici della Basilica dei Santi Cosma e Damiano a Roma: studio analitico delle tessere vitree. Riv. Stazione Sperimentale del Vetro 32 no. 5 13-24

[19] Verità M and Santopadre $\mathrm{P} 1993$ Le analisi delle tessere musive vitree: esempi d' applicazione nelle indagini preliminari al restauro del mosaico absidale della Cappella dei Santi Primo e Feliciano in S. Stefano Rotondo a Roma. Arte Medioevale, II serie VII, no. 1, 197-228

[20] Verità M and Santopadre P 2009 Mosaico absidale della basilica di Santa Cecilia a Roma. Studio delle tessere vitree. in: Restauri a Santa Cecilia, a cura di Daila Radeglia. (Florence: Edifir) pp. 263-72 